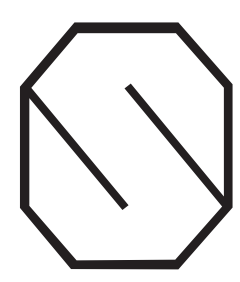

\title{
The Dynamics of Central Control and Subsidiary Autonomy in the Management of Human Resources: Case-Study Evidence from US MNCs in the UK
}

\author{
Anthony Ferner Phil Almond, lan Clark, Trevor Colling, Tony \\ Edwards, Len Holden and Michael Muller-Camen
}

Anthony Ferner

Phil Almond

Ian Clark

Trevor Colling

Len Holden

De Montfort

University, UK

Tony Edwards

Kings College,

London, UK

\section{Michael Muller-}

\section{Camen}

International

University in

Germany,

Bruchsal,

Germany
Organization

Studies

25(3): 363-391

ISSN 0170-8406

Copyright (c) 2004

SAGE Publications

(London,

Thousand Oaks,

CA \& New Delhi)

\section{Abstract}

This article revisits a central question in the debates on the management of multinationals: the balance between centralized policy-making and subsidiary autonomy. It does so through data from a series of case studies on the management of human resources in American multinationals in the UK. Two strands of debate are confronted. The first is the literature on differences between multinationals of different national origins which has shown that US companies tend to be more centralized, standardized, and formalized in their management of human resources. It is argued that the literature has provided unconvincing explanations of this pattern, failing to link it to distinctive features of the American business system in which US multinationals are embedded. The second strand is the wider debate on the balance between centralization and decentralization in multinationals. It is argued that the literature neglects important features of this balance: the contingent oscillation between centralized and decentralized modes of operation and (relatedly) the way in which the balance is negotiated by organizational actors through micro-political processes whereby the external structural constraints on the company are defined and interpreted. In such negotiation, actors' leverage often derives from exploiting differences between the national business systems in which the multinational operates.

Keywords: US multinational companies, human resource management, centralization, subsidiary autonomy, power

This article uses case-study evidence on the management of employment relations in US multinational companies (MNCs) to consider a staple question of the literature on multinationals: the balance between centralized policymaking and subsidiary autonomy. It confronts two strands of debate. First, it addresses the body of research that has examined differences between MNCs of different national origins. US companies have been found to be more centralized, standardized, and formalized in their management of human resources and other employment-relations policies. While the findings of the present research are broadly in line with those of other studies, it tries to go beyond the existing literature to link observed patterns to distinctive features of the American business system in which these MNCs are 'embedded'.

Second, it explores the implications of its findings for some of the dominant themes of the familiar literature on the degree of central control over subsidiary operations. This is one of the key questions of multinational operation; it 
underlies much of the extensive debate on the need to balance global integration and local responsiveness, as well as associated themes of the rise of 'federal' or 'heterarchic' MNCs in which strategic capabilities and power resources are widely disseminated among international operating units. The issue is also fundamental to the question of management control in MNCs; for example, the extent to which centralized hierarchical decision-making processes can substituted by 'socialization' of employees into an international corporate culture. It will be argued that two features of the balance of centralization-decentralization are under-explored in the MNC literature. The first is the oscillation between centralized and decentralized modes of operation, reflecting short-term contingent managerial adaptations to the environment. The second is the related negotiation of the balance between centralization and decentralization through micro-political processes shaped by, but not determined by structural features of the corporation and its environment.

The following section addresses in more detail the literature on centralization-decentralization in general, and more specifically in relation to MNCs of different national origin. The third section explains the methodology of the present study. Thereafter, the findings from a study of US MNCs are presented. Lastly, the conclusion draws out some implications of the study for the existing literature and briefly discusses possible elaborations of the micro-political processes associated with centralization-decentralization.

\section{The Literature on Centralization and Decentralization in MNCs}

For decades, studies have shown that MNCs of different national origins exhibit distinctive patterns of centralized control and subsidiary autonomy in the management of human resource (HR) and industrial relations (IR) policies and practices, and more generally. The thrust of findings is that US MNCs are more centralized than those of other nationalities (for example, Child et al. 2000; Negandhi 1983; Young et al. 1985). Child et al. (2000: 159) in their study of acquired UK subsidiaries report, for example, that the 'American mode of post-acquisition management appears to be hands-on, forceful, oriented to quick results, and distinctive. The strength with which the apparently typical American pattern of management practice is reproduced in their UK acquisitions is undoubtedly enhanced by the greater influence that US acquirers were reported to exercise.'

As far as employment relations are concerned, the consensus is that while HR and IR decisions and policies are generally less centralized than in other business areas, US MNCs are more centralized on such issues than other multinationals. Headquarters (HQ) plays an important role in setting or influencing policy on payment systems, collective bargaining, communications, union recognition, and welfare and training policies (Bomers and Peterson 1977; Dunning 1998; Gunnigle 1995; Hamill 1984; Harzing 1999; Negandhi 1986; Roberts 1972; Young et al. 1985; Yuen and Kee 1993). In the 1970s, for example, Bomers and Peterson (1977) found that European 
MNCs decentralized IR much more than US MNCs. The latter 'tended to make industrial relations policy-making more of an integral part of general corporate management' (Bomers and Peterson 1977: 51). In the same vein, Kujawa (1979: 4-5, 13) argued that while European MNCs' headquarters tended to be indifferent to their US subsidiaries' recognition policies, in US MNCs such decisions were 'often impressed with parent company interests, and industrial relations are likely to be viewed as essential to competitive strategy'. Negandhi (1983) reported that there was significantly less autonomy for US subsidiaries compared with Japanese and German counterparts across such HR areas as training and lay-offs. US companies were also considerably more centralized on broader strategic management decisions concerning production scheduling, pricing, and the introduction of new products. Similarly, Young et al. (1985) found, on the basis of a survey of more than 150 foreign subsidiaries, that US firms had more centralized control over financial, production, and marketing decisions, and to a lesser extent over employment and personnel decisions on hiring and the recruitment of senior managers (see also Hamill 1984).

Not all studies are clear cut. The survey by Guest and Hoque (1996: 63) found that the higher level of parental influence in US-owned establishments in the UK fell short of significance, and that US MNCs were no less likely than other foreign MNCs to recognize unions. But here case-study evidence tends to clarify the position by suggesting that a non-union policy in US companies is driven by headquarters' concerns rather than being a laissez-faire adaptation to the permissive UK environment. Companies such as McDonald's, IBM or Hewlett-Packard, known for their philosophical objections to collective workforce representation, have transferred similar policies to many of their foreign operations (Roberts 1972; Gunnigle 1995; Royle 2000).

Such findings are reinforced by case-study research. Work on US MNCs in Scotland, for example, has reported strong headquarters intervention in a range of HR and IR policies (Martin and Beaumont 1999; Tayeb 1998; Tayeb and Thory 2001) in areas such as union recognition, recruitment, pay, and employee communications, especially through the use of global staff opinion surveys.

A second distinctive finding is that centralized policies in US MNCs tend to be associated with a higher degree of formalization (Bartlett and Ghoshal 1998; Child et al. 2000; Negandhi 1983) and standardization (Harzing 1999; Kopp 1994; Yuen and Kee 1993) in the management of subsidiaries. Thus, Bartlett and Ghoshal (1998: 186-188) suggest that cross-national integration in US MNCs relies more on formalization, which they define as the 'institutionalization of systems and procedures to guide choices' (1998: 80), compared with Japanese or European companies. Child et al. (2000: 159) refer to 'greater formalization being introduced than in other national groups, notably in the methods of securing market intelligence, the use of financial control systems, and communications'. Harzing's study (1999) of control mechanisms in subsidiaries found that US companies tend to use more formalized methods in general, and are less reliant on 'personal' control through expatriates than are, for example, German or Japanese companies. 
It should be noted that formalization is not a necessary condition for centralization, since central influence may be ensured through direct personal control by expatriate managers socialized in the culture and practices of the parent, as has frequently been reported to be the case for Japanese MNCs (for example, Bartlett and Ghoshal 1998). Nonetheless, in US MNCs formalized processes can be seen as encouraging centralization by providing channels for the exertion of central influence in a systematic codified form. Moreover, formalization can be seen as a facilitator of standardization (that is, having similar or identical policies across subsidiaries), since elements of policies and processes are explicitly formulated, providing a common framework of adoption. Thus Kopp (1994) found that US firms surveyed were much more likely than Japanese or European MNCs to have performance-evaluation measures that were standardized across all international operations.

In other words, US MNCs have a tendency to apply centralized policies in the same or similar ways through the use of standard formal systems across their global operating units. This is an important question because this processual characteristic of US MNCs is likely to throw light on the mechanisms whereby US headquarters exert influence over substantive policies in the subsidiaries. In other words, parent-company policies in substantive areas such as pay, employee involvement, training, or culture management may be transmitted to subsidiaries through explicit, formal, routinized systems that also permit highly standardized dissemination.

\section{Centralization and the Importance of Country of Origin}

These findings raise two interlinked sets of questions. First, few studies have advanced convincing explanations of national difference among MNCs. They tend not to trace back observable characteristics of US MNCs to specific features of the business system in which they are rooted, although there are important exceptions (for example, Wever 1995; Yuen and Kee 1993). Explanations, if offered at all, tend to be essentially culturalist, typically using Hofstede's (1980) categories, such as 'power distance' and 'uncertainty avoidance' (for example, Ngo et al. 1998). Such approaches, while extremely influential within the business literature, fail to address the question of the relationship of 'cultural values' to structural and institutional characteristics of national economic systems, and in their ahistorical bias lacks a sense of dynamic development within business systems. As a result, they explain very little about the way in which different national business systems shape MNC practice.

Nonetheless, there are strong grounds for expecting the patterns described above: a basic premise of the research is that US MNCs are embedded in the assumptions, practices, and institutions of the American business model (for an extended discussion, see Ferner 2000a). Therefore, if comparative international research suggests that US MNCs are relatively centralized, formalized, and standardized in their HR-IR policy, this may be partly explained by reference to elements of the US business system. Among these are, notably, the early development, as described by Chandler (1990) and 
others, of formal management functions and control systems, and the use of these 'organizational capabilities' to exert centralized strategic control over geographically dispersed firms (both within the USA and later internationally) operating across diverse product markets. A key aspect was the delegation of responsibilities to subunit managers within strategic parameters determined by head office and operationalized through formal management control systems. The tendency to centralization and formalization was reinforced by the systems developed to manage standardized mass production, including codified tasks and formalized job descriptions, which continued to influence management style even after the decline of classical mass production and the rise of more flexible Japanese-influenced variants such as 'lean production' (see, for example, Appelbaum and Batt 1994). As this account suggests, centralization in the US case went hand in hand with formalization and standardization.

Moreover, the New Deal model of IR based on company-level collective bargaining gave impetus to the deployment of standard formal systems within the firm. This arose from the emphasis on regulation of employment through a bureaucratic 'web of rules', centrally determined by union and company, regulating lay-offs, rehiring, and promotion (Kochan et al. 1986), as well as grievance resolution. Formal, standardized bureaucratic systems were also developed relatively early in the USA to manage the employment of the expanding white-collar occupational groups, both in unionized and non-union firms (Edwards 1979).

As a result of such traditions, American companies are likely to have codified and reproducible management systems that can be managed from a strategic centre, may be transferred easily to other contexts, and which are not highly dependent on tacit knowledge - to use a phrase employed by Taylor et al. (1996), US HR policies are likely to have high 'context generalizability'. As far as the HR function itself is concerned, a number of features of the US system have encouraged centralization. Notable among them has been the attempt by several of the most prominent US companies to deploy innovative 'welfare capitalist' HR policies, primarily as a means of binding the workforce to the company and keeping the threat of unionization at bay (Jacoby 1997). This has led to a strategic approach to HR policy-making, seen as crucial for securing workforce commitment and retaining management control. Such developments may well provide the capability for a strategic, centralized approach to international human resource management (HRM) as well. US MNCs are also likely to have the motive to transfer policies abroad, given the dominance of the US business system internationally, which is likely to promote a belief that US HRM practices represent best practice. Furthermore, the receptivity of host systems to American HR practices is likely to be increased by the sheer weight of US subsidiaries in many hosts, including the UK, where US foreign direct investment accounts for around half of all employment in foreign-owned enterprises (Dunning 1998).

A further limitation of the literature on country-of-origin differences is that existing research has relied predominantly upon survey-based, quantitative 
methods. As a result, much of the country-of-origin literature provides a broad snapshot of patterns rather than capturing the 'ebb and flow' of relationships between the corporate HQ and subsidiaries upon which the assimilation of country-of-origin characteristics in subsidiaries is built. Lastly, the predominantly survey-based literature does not tend to pick up the subtleties of the process whereby country-of-origin traits are adapted to and modified by the host environment. In consequence, it may overstate the degree of ethnocentricity of HRM by conflating HQ policy with actual practice. Lindholm et al. (1999), for example, report on a study of performance appraisal of host nationals in China, using semi-structured interviews to demonstrate that apparently standard international policies in MNCs may be applied differently in the local business environment.

\section{Centralization, the Country-of-Origin Effect, and the Broader Centralization-Autonomy Literature}

The second set of questions is rather broader. It concerns the relationship between the findings on MNC nationality and the more general literature on central control and subsidiary autonomy in MNCs. There has been an extensive and long-standing debate on the issue to which a brief overview cannot do justice. Nevertheless, a number of key themes emerge of relevance to the arguments of this article.

First, the literature on centralization-decentralization has had a strong structuralist focus, explaining the degree of centralization by reference to structural variables such as the relative size of subsidiary and parent, the importance of the subsidiary for the parent's overall performance, the age of the subsidiary, whether it is greenfield or brownfield, and the degree of international integration of operations (for a summary, see Edwards et al. 1993). The degree of centralization has been linked to the function performed by different subsidiaries within the overall corporation (for example, Taylor et al. 1996; Doz and Prahalad 1994; Bird et al. 1998), and to the substantive issue - financial and market decisions being more centralized than HR and IR (see above). Within HR, issues such as pay rates and industrial relations have been more decentralized than policies on management development, pay systems or culture management because there is more pressure on the former to be 'isomorphic' to local business cultures (Rosenzweig and Nohria 1994). The 'resource-based' strand of literature, as propounded by writers such as Taylor et al. (1996), also factors in the variable motivation of MNCs to control HR practices in the subsidiaries, reflecting the degree to which particular practices are regarded by strategic decision-makers as crucial for international competitive advantage.

Second, much of the literature is essentially functionalist in orientation. Particular patterns of centralization-decentralization emerge that are seen as appropriate to (functional for) a particular set of environmental challenges and constraints. It is the job of senior executives to ensure the "configuration of assets and capabilities' (Bartlett and Ghoshal 1998: 67) correspond to the competitive strategy being adopted. The schema presented by Bartlett and 
Ghoshal (1998: Ch. 4) is well known: 'multinational' companies have a 'decentralized and nationally self-sufficient' allocation of responsibilities; 'global' firms are 'centralized and globally scaled'; 'international' companies centralize some core competences and decentralize others; while 'transnational' companies operate according to 'flexible centralization' in which specialist responsibilities are dispersed among differentiated operating units linked by strong interdependencies in an 'integrated network configuration' (1998: 68, 75).

Third, the conceptualization of the balance between centralization and decentralization is frequently underpinned by an evolutionary notion of 'stages of development': a systematic evolution of MNCs, both in terms of broad historical patterns and within the life cycle of individual MNCs, responding to the evolving structural conditions that confront them (for example, Perlmutter 1969; Bartlett and Ghoshal 1998; Martínez and Jarillo 1989). Within the field of HR-IR, there is an analogous literature which ascribes patterns of centralization-decentralization to the particular phase of an MNC's international development (for example, Adler and Ghadar 1990; Dowling et al. 1999). Some writers (for example, Bartlett and Ghoshal 1998; Mtar 2001) argue that the country-of-origin impact seen in the degree of centralization of control partly reflects the historical phase of evolution of the international economy at the time at which MNCs internationalized. For example, the wave of internationalization by US companies in the early postwar period took place under conditions that permitted a high degree of standardization and was marked by the transfer of domestic capabilities to overseas operations (Bartlett and Ghoshal 1998: Ch. 3; Dunning 1998).

While many writers are careful to distance themselves from suggestions that there is a unilinear developmental tendency at work, there is much less discussion of more contingent dynamics of centralization and autonomy. Yet such concerns have a long tradition in the literature. Brooke (1984; Brooke and Remmers 1970: Ch. 3), for example, portrays a constant 'fluctuation around the normal line' (1970: 64) between centralized control and subsidiary autonomy. This dynamic is generated by the centre's reaction to poor subsidiary performance, leading to renewed centralization, followed by a loss of key local personnel, a lack of initiative in the subsidiary, and pressures for renewed autonomy.

Fourth, the literature's concentration on structural explanations, functional fit, and stages of development gives rise to another striking characteristic of accounts of the centralization-decentralization balance: the neglect of power. Power is not totally unconsidered. For example, Bartlett and Ghoshal (1998: 186-188) argue that formalization, by routinizing decision-making, is appropriate for situations in which subsidiaries have countervailing power and are therefore likely to be able to resist central policy imposition. Similarly, Ghoshal and Nohria $(1989,1993)$ use a resource-dependency approach to argue that the degree of central control over subsidiaries is conditioned by the mutual dependency of HQ and subsidiaries on resources provided by the other. As resource levels of the subsidiary increase, interests with HQ may diverge and HQ dependency on the subsidiary may increase. Ghoshal and 
Nohria hypothesize that centralization will be less where local resources are high; centralization would cause 'severe dissonance' in such circumstances (1989: 326).

Such accounts do not, however, analyse (or give direct evidence of) the way in which organizational micro-politics shapes the balance between centralization and subsidiary autonomy; they merely state that internal power relations depend on the configuration of resources. Similarly, Bartlett and Ghoshal (1998) pay homage to the importance of organizational power, but do not follow through the implications of their arguments. Thus, they refer (Bartlett and Ghoshal 1998: 78) to the way in which groups responding to the most critical strategic tasks within an MNC gain organizational power (for example, product divisions dominated decision-making in Matsushita since a strategy of global-scale efficiency depended on strong business management). This raises the question of how the strategic thrust was defined in the first place, and the extent to which the power arising out of strategic position begets further power. In addition, despite references to power, the thrust of much of the literature is overwhelmingly based on the assumption that the appropriate level of centralization or autonomy is determined in a hierarchical way by top corporate executives. As Forsgren (1990) argues in criticizing this 'hierarchical' perspective, subsidiaries develop their own objectives and have inherent power.

It will be a principal argument of this article that subsidiaries' access to power resources gives rise to important processes of micro-political negotiation over the balance between centralization and subsidiary autonomy, within the limits set by such structural characteristics as those referred to above. On the one hand, structural changes, both externally in markets and technologies and internally in, for example, organizational structures, set limits to the margin of manoeuvre of corporate actors, but on the other hand, provide them with an evolving set of resources which they may deploy in pursuit of their individual and collective interests within the wider corporation.

\section{The Study}

The findings presented in this article are based on data from the British leg of a study in progress of US MNCs in four European countries: Britain, Germany, Ireland, and Spain. The broad objectives of the research are to identify the influence of the US business system on the management of employment relations in US MNCs and to explore by means of in-depth case studies the mechanisms whereby such influence is transmitted. Unlike most studies, both survey and case study, the research has aimed to combine the headquarters' 'view from above' with the subsidiaries' 'view from below' by conducting research at both levels. The study set out to explore the distinctive logic of action of HR decision-making in US MNCs by examining a set of processual issues including the degree of centralization and formalization in relations between subsidiary and HQ, the forms of management control, 
and the mechanisms through which policies and practices are diffused to subsidiaries. These issues are investigated through the examination of substantive HR areas such as performance management, participation and involvement, collective relations, and work organization.

Fieldwork on the British part of the project, funded by the ESRC, began in the spring of 1999. In-depth case studies are currently being carried out in seven British subsidiaries of US companies, in IT, consumer goods, household products, engineering contracting, and mechanical engineering. A further four to six in-depth case studies are in progress in sectors including business services and chemicals and pharmaceuticals. These are supplemented by a number of less detailed cases. The case studies drawn on in this article are shown in Table 1. For reasons of confidentiality, pseudonyms are used.

Around 70 interviews have so far been conducted with respondents from $\mathrm{HR}$, finance, and operations functions in UK subsidiaries, and in five of the companies, a further 17 interviews have been carried out at the corporate or European HQ, or both. Interviews are taped, fully transcribed, and coded using QSR N5 data-analysis software. To ensure a degree of consistency across cases and countries, all teams work to a detailed common template of issues, common interview schedules, and a shared coding scheme.

Interviews are supplemented by a wide range of documentary material on the case companies, including published information such as annual reports, companies' Securities and Exchange Commission submissions (form 10K), and company websites, in order to give a picture of general corporate activity and structural characteristics, and their evolution over time.

Table 1.

Case-Study Firms

\begin{tabular}{|c|c|c|c|c|}
\hline \multirow[t]{2}{*}{ Firm } & \multirow[t]{2}{*}{ Sector } & \multicolumn{3}{|l|}{ Interviews } \\
\hline & & $\begin{array}{l}\text { UK } \\
\text { subsidiary }\end{array}$ & $\begin{array}{l}\text { European } \\
\text { and US HQ }\end{array}$ & $\begin{array}{l}\text { Other } \\
\text { European } \\
\text { subsidiaries }\end{array}$ \\
\hline EngCo1 & mechanical engineering & 15 & $2^{\mathrm{a}}$ & - \\
\hline EngCo2 & mechanical engineering & 6 & 5 & - \\
\hline Eng Servs & civil engineering contracting & 16 & 1 & 3 \\
\hline FMCG & consumer goods & 3 & 5 & 6 \\
\hline RefreshCo & food \& drink & 1 & - & 4 \\
\hline Household1 & chemicals \& household products & 6 & 2 & - \\
\hline Household $2^{b}$ & chemicals \& household products & 1 & - & 1 \\
\hline ITco & IT services & 19 & 8 & 9 \\
\hline PharmaChem $^{\text {b }}$ & pharmaceuticals \& chemicals & 2 & - & 1 \\
\hline Total & & 69 & 23 & 24 \\
\hline
\end{tabular}

Notes:

a In addition, interviews were conducted with two senior expatriate respondents in the UK subsidiaries who are also members of the international product division executive board.

b Two small-scale case studies (Household2 and PharmaChem) are also included for comparative purposes. 


\section{The Centralization-Decentralization Dynamic in US MNCs in Britain: Empirical Evidence}

This section uses empirical findings to examine two elements of the centralization-autonomy balance under-emphasized in the literature: the 'oscillation' between modes and the way in which corporate actors constantly mobilize resources to negotiate the terms of the balance between central control and subsidiary autonomy.

\section{Centralization, Formalization, and Standardization}

On the whole, the case studies confirm the picture of centrally devised policies disseminated globally (see Table 2 for a summary of the findings). Only one subsidiary, Eng Servs, was distinctive in being managed in a fairly decentralized way. This distinctiveness reflected structural factors such as the relative size of the UK subsidiary and the nature of the sector in which operations were high value and high risk while requiring detailed local knowledge. But it also reflected the fact that the UK subsidiary of Eng Servs was the largest and most profitable unit worldwide for its business division. This was in large measure the result of the entrepreneurial business approach of the UK operation, for example, in pioneering expansion into promising Far Eastern markets (see Colling and Clark 2002).

For the others, common global (or international business division) policy was particularly evident in areas such as performance management and the accompanying systems of target-setting and appraisal; remuneration, including bonuses and performance-related pay, employee share ownership, and market positioning on pay levels; communication, culture, and values; and management development and training (Table 2). The extent to which policies were mandated, recommended, or simply available to subsidiaries 'off-the-shelf' varied with the company and the issue. Policies on pay and appraisal for senior staff tended to be highly prescribed, with more latitude for the management of non-managerial employees. For example, formal global performanceappraisal systems often stopped at the level of first-line management. In many cases, central policy dictated a general framework within which subsidiaries had a relative freedom to adapt to local circumstances.

Increasingly, the main level driving HR policy was, as in many MNCs (Marginson and Sisson 1994), the international business division, reflecting the increasing international integration of productive activity within companies. The regional level, too, was growing in importance, often through business-geography matrices. In seven of the nine companies listed in Table 1, there was a significant European headquarters (sometimes covering other geographical areas as well). In ITco, for example, HR functions and policymaking were being centralized in Europe-wide units covering areas such as graduate recruitment, international assignments, and HR support and advice. This led to a marked reduction in the autonomy and influence of national subsidiaries. Europeanization of corporate structures clearly reflected the growing integration of the regional economy as a result of the Single 
European Market. In several companies, production facilities were being rationalized across Europe (for example, Household1 and Household2), so it increasingly made sense to consider the European region as a whole. The Europeanized structures also responded to the emergence of a distinct 'regulatory space' in the European Union (Marginson 2000). In the HR area, issues such as working time, parental leave, and employee representation were shaped by EU directives. From the point of view of corporate HQ, the European level was a means of clarifying communications by aggregating inputs from a diverse range of countries. It was also a response to cost-cutting pressures: money could be saved by consolidating HR and other services at European level, and by locating labour-intensive functions (such as HR support centres) in countries where labour costs were relatively low and labour flexibility high (for example, in regards to shift-working).

The rising importance of the regional level could be at the expense of the national subsidiary, as in ITCo and FMCG, and could mean the loss of status and authority for national HR personnel. However, this was not necessarily the case. In Refreshco, for example, a massive decentralization from corporate HQ filtered down to the national level, with the transfer of responsibilities for a range of policies, such as performance management, grading, pay and bonuses, and diversity, previously standardized at headquarters.

Centralization of HR also covered substantive areas that were distinctively American. First, the concern of companies to harness the tools of social science to understand the motivation and attitudes of their workforce (see especially Jacoby 1997) was evident in the use by most companies of regular employee opinion surveys that were centrally designed, mandatory, and applied in a standardized way to subsidiaries worldwide. Normally, the results would be collated and monitored centrally and if local subsidiaries showed poor results in particular areas, they would be expected to devise plans for improvement. The survey could be explicitly linked, as in Household2, with the guiding values of the corporation.

Second, in some companies, notably EngCo2 and $F M C G$, there were mandatory global policies on workforce 'diversity'. In one, the policy included global targets for women in senior posts; in the other, foreign affiliates were expected to define the content of 'diversity' according to the circumstances of the host environment, but there was a common framework of diversity training and each site worldwide set up 'diversity councils' as a channel for workforce views on diversity and as a vehicle for defining the 'business case' for diversity. A third company, Refreshco, had only very recently moved away from a highly standardized global diversity policy which had entailed the detailed central collection of a variety of diversity statistics. Even after decentralization, this company still insisted that subsidiaries have an employment-diversity policy reflecting the composition of the customers they served (a theme common to several companies). Details were left to subsidiaries, but here and in other companies, progress was monitored by higher levels. In ITco, there was no mandatory global policy, but there was a corporate vice-president with responsibility for encouraging diversity globally, and groups were set up in subsidiaries to set 
Table 2 Centralization-Decentralization of HR and IR policy

\begin{tabular}{|c|c|c|c|c|c|c|c|c|}
\hline Firm & General & $\begin{array}{l}\text { Role of Europe/ } \\
\text { region \& } \\
\text { international } \\
\text { business divisions }\end{array}$ & $\begin{array}{l}\text { Involvement of } \\
\text { subsidiary in } \\
\text { HR policy } \\
\text { formation }\end{array}$ & $\begin{array}{l}\text { Substantive } \\
\text { issues: pay \& } \\
\text { performance } \\
\text { management }\end{array}$ & $\begin{array}{l}\text { Management } \\
\text { development } \\
\text { and training }\end{array}$ & $\begin{array}{l}\text { Communications } \\
\text { cultural values, } \\
\text { diversity }\end{array}$ & $\begin{array}{l}\text { Unions and } \\
\text { collective } \\
\text { relations/ EWC }\end{array}$ & $\begin{array}{l}\text { Work organization } \\
\text { (for manufacturing } \\
\text { companies) }\end{array}$ \\
\hline Eng Servs & $\begin{array}{l}\text { Relative weakness } \\
\text { of central financial } \\
\text { and HR systems; } \\
\text { but pressures for } \\
\text { globalization } \\
\text { leading to review } \\
\text { of functions } \\
\text { including HR }\end{array}$ & $\begin{array}{l}\text { European HQ with } \\
\text { strong policy role } \\
\text { in HR and other } \\
\text { matters, but not } \\
\text { covering business } \\
\text { division that the } \\
\text { UK is part of }\end{array}$ & $\begin{array}{l}\text { UK's own } \\
\text { appraisal system } \\
\text { for engineers } \\
\text { taken up as } \\
\text { corporate model }\end{array}$ & $\begin{array}{l}\text { Performance- } \\
\text { related pay } \\
\text { system devised } \\
\text { in UK } \\
\text { New appraisal } \\
\text { system focusing } \\
\text { on individual } \\
\text { but driven from } \\
\text { the UK }\end{array}$ & & $\begin{array}{l}\text { No regular } \\
\text { global } \\
\text { employee } \\
\text { opinion survey }\end{array}$ & $\begin{array}{l}\text { Central } \\
\text { intervention on } \\
\text { European } \\
\text { subsidiaries' } \\
\text { EWC policy }\end{array}$ & $\begin{array}{l}\text { Little central } \\
\text { influence, no } \\
\text { international } \\
\text { benchmarking; } \\
\text { UK often in } \\
\text { vanguard on work } \\
\text { organization } \\
\text { issues }\end{array}$ \\
\hline Engco1 & $\begin{array}{l}\text { Network-based } \\
\text { 'pooled' control } \\
\text { rather than } \\
\text { 'command \& } \\
\text { control' policy } \\
\text { Much central } \\
\text { policy notionally } \\
\text { optional, but non- } \\
\text { compliance needs } \\
\text { to be justified }\end{array}$ & $\begin{array}{l}\text { Weak coordination } \\
\text { in Europe above } \\
\text { country level } \\
\text { Move to strong } \\
\text { international } \\
\text { business divisions } \\
\text { from } 1990 \mathrm{~s}\end{array}$ & $\begin{array}{l}\text { Subsidiary } \\
\text { sometimes } \\
\text { originates policy } \\
\text { that gets taken } \\
\text { up by the } \\
\text { corporation (e.g. } \\
\text { shared services, } \\
\text { teamworking) }\end{array}$ & $\begin{array}{l}\text { Development and } \\
\text { performance } \\
\text { appraisal system } \\
\text { globally } \\
\text { mandated (scope } \\
\text { for local } \\
\text { adaptation) } \\
\text { Global bonuses } \\
\text { and share } \\
\text { purchase policies }\end{array}$ & $\begin{array}{l}\text { Central } \\
\text { monitoring of } \\
\text { senior } \\
\text { management } \\
\text { pool }\end{array}$ & $\begin{array}{l}\text { Mandated } \\
\text { 'cultural values', } \\
\text { detail left to } \\
\text { affiliates; de facto } \\
\text { commonality } \\
\text { within businesses } \\
\text { Global, standard } \\
\text { opinion survey } \\
\text { with central } \\
\text { monitoring }\end{array}$ & $\begin{array}{l}\text { Formal global } \\
\text { principle of } \\
\text { employees not } \\
\text { feeling the need } \\
\text { for unions, but } \\
\text { detailed policy } \\
\text { left to subsidiary } \\
\text { with little central } \\
\text { involvement }\end{array}$ & $\begin{array}{l}\text { Teamworking: } \\
\text { form, content, link } \\
\text { with pay level etc. } \\
\text { left to affiliate, but } \\
\text { some interchange } \\
\text { of ideas between } \\
\text { countries }\end{array}$ \\
\hline Engco2 & $\begin{array}{l}\text { Direct influence of } \\
\text { owner \& family } \\
\text { on company } \\
\text { 'ethos' } \\
\text { Strong central } \\
\text { influence; cost- } \\
\text { driven } \\
\text { standardization, } \\
\text { subsidiaries have } \\
\text { to make 'business } \\
\text { reasons' case for } \\
\text { adaptating global } \\
\text { policies locally }\end{array}$ & $\begin{array}{l}\text { International } \\
\text { business division } \\
\text { increasingly } \\
\text { important, but } \\
\text { regions less so; } \\
\text { HR director of } \\
\text { one division is } \\
\text { UK-based }\end{array}$ & $\begin{array}{l}\text { Growing } \\
\text { subsidiary } \\
\text { demands for } \\
\text { involvement in } \\
\text { global HR } \\
\text { policy process }\end{array}$ & $\begin{array}{l}\text { Growing global } \\
\text { standardization } \\
\text { of performance } \\
\text { management } \\
\text { policy } \\
\text { Intended global } \\
\text { policy of using } \\
\text { appraised } \\
\text { performance to } \\
\text { weed out under- } \\
\text { performing } \\
\text { employees } \\
\text { Global policy to } \\
\text { be at median } \\
\text { pay levels }\end{array}$ & $\begin{array}{l}\text { Intention to } \\
\text { standardize } \\
\text { global training } \\
\text { \& development } \\
\text { systems }\end{array}$ & $\begin{array}{l}\text { Formal worldwide } \\
\text { mission being } \\
\text { introduced, based } \\
\text { on consultation } \\
\text { with subsidiaries } \\
\text { Worldwide open- } \\
\text { door policy } \\
\text { Strong global } \\
\text { diversity policy } \\
\text { with common } \\
\text { elements world- } \\
\text { wide (e.g. staff } \\
\text { diversity groups, } \\
\text { training content) }\end{array}$ & $\begin{array}{l}\text { Owner-driven } \\
\text { corporate ethos } \\
\text { of seeing unions } \\
\text { as a check on } \\
\text { management, but } \\
\text { good working } \\
\text { relations with } \\
\text { unions in the UK } \\
\text { subsidiary }\end{array}$ & $\begin{array}{l}\text { Team-based } \\
\text { production } \\
\text { systems common } \\
\text { across plants, but } \\
\text { local autonomy on } \\
\text { detail }\end{array}$ \\
\hline
\end{tabular}




\begin{tabular}{|c|c|c|c|c|c|c|c|c|}
\hline Firm & General & $\begin{array}{l}\text { Role of Europe/ } \\
\text { region \& } \\
\text { international } \\
\text { business divisions }\end{array}$ & $\begin{array}{l}\text { Involvement of } \\
\text { subsidiary in } \\
\text { HR policy } \\
\text { formation }\end{array}$ & $\begin{array}{l}\text { Substantive } \\
\text { issues: pay \& } \\
\text { performance } \\
\text { management }\end{array}$ & $\begin{array}{l}\text { Management } \\
\text { development } \\
\text { and training }\end{array}$ & $\begin{array}{l}\text { Communications } \\
\text { cultural values, } \\
\text { diversity }\end{array}$ & $\begin{array}{l}\text { Unions and } \\
\text { collective } \\
\text { relations/ EWC }\end{array}$ & $\begin{array}{l}\text { Work organization } \\
\text { (for manufacturing } \\
\text { companies) }\end{array}$ \\
\hline FMCG & $\begin{array}{l}\text { Increasing HR } \\
\text { autonomy for } \\
\text { international } \\
\text { business divisions, } \\
\text { sometimes } \\
\text { conflicting with } \\
\text { centralization } \\
\text { within regions }\end{array}$ & $\begin{array}{l}\text { Increasing } \\
\text { centralization } \\
\text { within region (e.g. } \\
\text { approval of senior } \\
\text { appointments) } \\
\text { Some Europe-level } \\
\text { functions (e.g. } \\
\text { remuneration) } \\
\text { contracted to } \\
\text { country operations } \\
\text { Use of virtual } \\
\text { European } \\
\text { structures }\end{array}$ & $\begin{array}{l}\text { Stronger } \\
\text { subsidiaries more } \\
\text { able to win local } \\
\text { flexibility from } \\
\text { HQ }\end{array}$ & $\begin{array}{l}\text { Global employee } \\
\text { ESOPs } \\
\text { Prescriptive } \\
\text { central guidelines } \\
\text { on pay (e.g. at } \\
\text { risk percentage } \\
\text { in bonus scheme) } \\
\text { Global senior } \\
\text { management } \\
\text { performance } \\
\text { scheme linked to } \\
\text { corporate values } \\
\text { Global policy of } \\
\text { pay being at mid- } \\
\text { point of market }\end{array}$ & $\begin{array}{l}\text { Global system } \\
\text { of identifying } \\
\text { high potentials, } \\
\text { coordinated } \\
\text { from HQ } \\
40 \text { hours' training } \\
\text { per employee, } \\
\text { centrally } \\
\text { monitored }\end{array}$ & $\begin{array}{l}\text { Central global } \\
\text { opinion survey, } \\
\text { linked to senior } \\
\text { subsidiary } \\
\text { managers' } \\
\text { performance } \\
\text { measurement } \\
\text { Cultural values } \\
\text { driven from } \\
\text { centre, formalized } \\
\text { relatively recently } \\
\text { Worldwide } \\
\text { diversity policy } \\
\text { with metrics and } \\
\text { link to appraisal; } \\
\text { detail left to } \\
\text { affiliates, but must } \\
\text { include gender } \\
\text { issues }\end{array}$ & $\begin{array}{l}\text { Dealing with } \\
\text { unions is a local } \\
\text { issue, but HQ } \\
\text { ethos questions } \\
\text { the need for } \\
\text { unions }\end{array}$ & $\begin{array}{l}\text { Increasing } \\
\text { benchmarking } \\
\text { between plants } \\
\text { internationally in } \\
\text { terms of best } \\
\text { practice }\end{array}$ \\
\hline Household1 & $\begin{array}{l}\text { Impact of } \\
\text { owning family } \\
\text { still strong: UK } \\
\text { plant closure } \\
\text { plan vetoed by } \\
\text { owner } \\
\text { Global } \\
\text { restructuring } \\
\text { \& rationalization } \\
\text { initiatives } \\
\text { In HR, tendency } \\
\text { to centralization } \\
\text { and globalization } \\
\text { though with local } \\
\text { flexibility }\end{array}$ & $\begin{array}{l}\text { Growing } \\
\text { importance of } \\
\text { European regional } \\
\text { level, leading to } \\
\text { reduction in } \\
\text { country autonomy } \\
\text { National HR } \\
\text { managers have } \\
\text { European } \\
\text { responsibilities } \\
\text { Shared HR (and } \\
\text { other) services for } \\
\text { Europe located in } \\
\text { London }\end{array}$ & $\begin{array}{l}\text { Local flexibility } \\
\text { within central } \\
\text { policy } \\
\text { Local } \\
\text { subsidiaries can } \\
\text { influence central } \\
\text { policy by } \\
\text { pointing out } \\
\text { 'problems'; } \\
\text { anxiety not to } \\
\text { 'reinvent the } \\
\text { wheel' }\end{array}$ & $\begin{array}{l}\text { Pay and benefits } \\
\text { globally driven }\end{array}$ & $\begin{array}{l}\text { Standardized } \\
\text { global training } \\
\text { for appraisal/ } \\
\text { grading/ } \\
\text { competence } \\
\text { system }\end{array}$ & $\begin{array}{l}\text { Open-door } \\
\text { policy worldwide } \\
\text { Standard global } \\
\text { corporate values } \\
\text { statement } \\
\text { Triennial global } \\
\text { staff survey; } \\
\text { annual European } \\
\text { survey } \\
\text { Strong global } \\
\text { diversity policy, } \\
\text { employee groups } \\
\text { for women, ethnic } \\
\text { and sexual } \\
\text { minorities, etc. }\end{array}$ & $\begin{array}{l}\text { Informal ethos of } \\
\text { not recognizing } \\
\text { unions ideally, } \\
\text { but working with } \\
\text { them where they } \\
\text { exist }\end{array}$ & $\begin{array}{l}\text { Global policy of } \\
\text { high-performance } \\
\text { work teams, but } \\
\text { implemented } \\
\text { differently in } \\
\text { different countries }\end{array}$ \\
\hline
\end{tabular}




\begin{tabular}{|c|c|c|c|c|c|c|c|c|}
\hline Firm & General & $\begin{array}{l}\text { Role of Europe/ } \\
\text { region \& } \\
\text { international } \\
\text { business divisions }\end{array}$ & $\begin{array}{l}\text { Involvement of } \\
\text { subsidiary in } \\
\text { HR policy } \\
\text { formation }\end{array}$ & $\begin{array}{l}\text { Substantive } \\
\text { issues: pay \& } \\
\text { performance } \\
\text { management }\end{array}$ & $\begin{array}{l}\text { Management } \\
\text { development } \\
\text { and training }\end{array}$ & $\begin{array}{l}\text { Communications } \\
\text { cultural values, } \\
\text { diversity }\end{array}$ & $\begin{array}{l}\text { Unions and } \\
\text { collective } \\
\text { relations/ EWC }\end{array}$ & $\begin{array}{l}\text { Work organization } \\
\text { (for manufacturing } \\
\text { companies) }\end{array}$ \\
\hline & $\begin{array}{l}\text { Recent move to } \\
\text { business divisions; } \\
\text { businesses } \\
\text { dominate business/ } \\
\text { region matrix }\end{array}$ & & & & & & & \\
\hline Household2 & $\begin{array}{l}\text { Considerable } \\
\text { devolution of HR } \\
\text { to European } \\
\text { region }\end{array}$ & $\begin{array}{l}\text { Europe able to } \\
\text { challenge central } \\
\text { HR policy } \\
\text { guidelines } \\
\text { European role in } \\
\text { headcount control, } \\
\text { training, executive } \\
\text { compensation; } \\
\text { European project } \\
\text { teams to handle } \\
\text { plant closures }\end{array}$ & $\begin{array}{l}\text { Significant HR } \\
\text { flexibility in } \\
\text { subsidiary, } \\
\text { within central } \\
\text { framework of } \\
\text { values }\end{array}$ & $\begin{array}{l}\text { Pay \& appraisal } \\
\text { systems } \\
\text { developed in } \\
\text { Europe } \\
\text { Executive } \\
\text { compensation } \\
\text { worldwide }\end{array}$ & $\begin{array}{l}\text { Global } \\
\text { succession } \\
\text { planning } \\
\text { Standardized } \\
\text { leadership } \\
\text { competences \& } \\
\text { training in } \\
\text { Europe }\end{array}$ & $\begin{array}{l}\text { Very influential, } \\
\text { long-standing, } \\
\text { globally mandated } \\
\text { statement of } \\
\text { corporate values } \\
\text { Standard global } \\
\text { employee survey }\end{array}$ & $\begin{array}{l}\text { Global culture of } \\
\text { avoiding unions } \\
\text { if possible, but } \\
\text { cooperation } \\
\text { where they exist }\end{array}$ & \\
\hline ITco & $\begin{array}{l}\text { Fluctuations from } \\
\text { highly centralized, } \\
\text { to countries, to } \\
\text { regions/global } \\
\text { businesses }\end{array}$ & $\begin{array}{l}\text { 1990s away from } \\
\text { 'country-centred' } \\
\text { HR to } \\
\text { centralization } \\
\text { within Europe, with } \\
\text { Europe-level HR } \\
\text { call centre, } \\
\text { graduate } \\
\text { recruitment, } \\
\text { management of } \\
\text { international } \\
\text { assignments }\end{array}$ & $\begin{array}{l}\text { Affiliates' role } \\
\text { in global policy } \\
\text { development (e.g. } \\
\text { induction policy) } \\
\text { Appraisal system } \\
\text { seen as } \\
\text { developed in } \\
\text { the UK, then } \\
\text { globalized }\end{array}$ & $\begin{array}{l}\text { Performance- } \\
\text { related pay a } \\
\text { fundamental } \\
\text { tenet } \\
\text { Global appraisal } \\
\text { and worldwide } \\
\text { bonus system } \\
\text { based on } \\
\text { business results } \\
\text { and appraisal } \\
\text { rating } \\
\text { Centrally driven } \\
\text { leadership } \\
\text { competences } \\
\text { model }\end{array}$ & $\begin{array}{l}\text { Standardized } \\
\text { management of } \\
\text { executive } \\
\text { resources } \\
\text { through } \\
\text { leadership } \\
\text { competences } \\
\text { and training } \\
\text { European model } \\
\text { of assessment } \\
\text { centres for } \\
\text { graduates }\end{array}$ & $\begin{array}{l}\text { Global staff } \\
\text { survey } \\
\text { Europeanization } \\
\text { of communications } \\
\text { - away from } \\
\text { country-based } \\
\text { 'flavour' }\end{array}$ & $\begin{array}{l}\text { Strong global } \\
\text { culture of union } \\
\text { avoidance where } \\
\text { possible, but } \\
\text { some 'backdoor' } \\
\text { unionization } \\
\text { through } \\
\text { acquisition of } \\
\text { outsourced IT } \\
\text { workforces }\end{array}$ & \\
\hline
\end{tabular}




\begin{tabular}{|c|c|c|c|c|c|c|c|c|}
\hline Firm & General & $\begin{array}{l}\text { Role of Europe/ } \\
\text { region \& } \\
\text { international } \\
\text { business divisions }\end{array}$ & $\begin{array}{l}\text { Involvement of } \\
\text { subsidiary in } \\
\text { HR policy } \\
\text { formation }\end{array}$ & $\begin{array}{l}\text { Substantive } \\
\text { issues: pay \& } \\
\text { performance } \\
\text { management }\end{array}$ & $\begin{array}{l}\text { Management } \\
\text { development } \\
\text { and training }\end{array}$ & $\begin{array}{l}\text { Communications } \\
\text { cultural values, } \\
\text { diversity }\end{array}$ & $\begin{array}{l}\text { Unions and } \\
\text { collective } \\
\text { relations/ EWC }\end{array}$ & $\begin{array}{l}\text { Work organization } \\
\text { (for manufacturing } \\
\text { companies) }\end{array}$ \\
\hline PharmaChem & $\begin{array}{l}\text { Creeping } \\
\text { centralization of } \\
\text { HR following } \\
\text { merger, 'top- } \\
\text { down', 'tablets } \\
\text { of stone' approach } \\
\text { to HR policy }\end{array}$ & $\begin{array}{l}\text { European HR } \\
\text { function composed } \\
\text { of country HR } \\
\text { managers with } \\
\text { European } \\
\text { responsibilities }\end{array}$ & $\begin{array}{l}\text { Little subsidiary } \\
\text { input into } \\
\text { international } \\
\text { policy }\end{array}$ & $\begin{array}{l}\text { Mandated rigid } \\
\text { performance- } \\
\text { appraisal system } \\
\text { Global system } \\
\text { of base pay and } \\
\text { stock options and } \\
\text { bonus scheme } \\
\text { Policy of median } \\
\text { base pay levels } \\
\text { Increasing } \\
\text { direct intervention } \\
\text { in pay from USA } \\
\text { (e.g. cap on pay } \\
\text { rises) }\end{array}$ & $\begin{array}{l}\text { Bureaucratic } \\
\text { global system of } \\
\text { management } \\
\text { development \& } \\
\text { succession } \\
\text { planning }\end{array}$ & $\begin{array}{l}\text { Cultural vision } \\
\text { and values } \\
\text { generic rather } \\
\text { than explicit }\end{array}$ & $\begin{array}{l}\text { IR seen as an area } \\
\text { of 'total freedom' } \\
\text { for subsidiaries, } \\
\text { though ethos of } \\
\text { union avoidance }\end{array}$ & \\
\hline RefreshCo & $\begin{array}{l}\text { Recent change } \\
\text { from highly } \\
\text { centralized to } \\
\text { decentralized HR, } \\
\text { reflecting refocus } \\
\text { on making 'global } \\
\text { brands local' }\end{array}$ & $\begin{array}{l}\text { Decentralization } \\
\text { from HQ to } 4 \\
\text { broad regional } \\
\text { units and a lower } \\
\text { level European } \\
\text { group comprising } \\
\text { individuals located } \\
\text { in national } \\
\text { subsidiaries }\end{array}$ & $\begin{array}{l}\text { Freedom to } \\
\text { design HR } \\
\text { policy locally } \\
\text { within European/ } \\
\text { global strategic } \\
\text { policy } \\
\text { frameworks }\end{array}$ & $\begin{array}{l}\text { Mandatory } \\
\text { performance- } \\
\text { related } \\
\text { remuneration, but } \\
\text { details now left } \\
\text { to subsidiaries - } \\
\text { previously tightly } \\
\text { prescribed from } \\
\text { USA }\end{array}$ & $\begin{array}{l}\text { Previous } \\
\text { provision of } \\
\text { function-based } \\
\text { induction } \\
\text { training from } \\
\text { HQ - cut with } \\
\text { restructuring, } \\
\text { leading to a } \\
\text { vacuum }\end{array}$ & $\begin{array}{l}\text { Framework of } \\
\text { cultural values } \\
\text { Worldwide } \\
\text { diversity ethos } \\
\text { with central } \\
\text { monitoring; } \\
\text { content now } \\
\text { left to subsidiaries }\end{array}$ & No unions in GB & \\
\hline
\end{tabular}


targets for the recruitment of women to leadership positions and to track progress.

This emphasis on diversity was a clear reflection of the US domestic policy agenda, linked to affirmative action legislation on race and gender, and to companies' concerns both to widen the pool of scarce professional and managerial skills and to reflect a culturally and ethnically heterogeneous customer base in the domestic market. Nonetheless, diversity was driven ethnocentrically as a global policy. Sometimes this had counter-productive results, as when one company attempted to diffuse new policies on the treatment of same-sex and unmarried couples, provoking strong reaction in some foreign subsidiaries where such policies were culturally controversial, and hence resulting in increased variation rather than greater standardization in policy across countries.

The standardized dissemination of such centrally devised policies may be seen also as reflecting a defining characteristic of many US firms: the huge size of the US domestic market, which in turn had traditionally meant that the foreign operations of many MNCs, though large in local terms, were a small proportion of total corporate activity. As a result, argued a number of UK managers, there was a tradition of parochial and inward-looking HR in which policies were designed centrally with the US workforce in mind and then disseminated to the company's operations worldwide. However, the international growth of companies meant that the weight of foreign employment was increasing. In EngCo2 and ITco, for example, more than half of all employment was outside the USA.

\section{Oscillation between Centralization and Subsidiary Autonomy}

Nevertheless, the findings also suggest significant qualifications to the arguments of the literature. First, as important as the degree of (de)centralization was the evidence of movement from one state to another. Particularly noticeable in some companies (for example, ITco and PharmaChem) was an oscillation between centralized and decentralized forms of management that also affected HR. ITco, for example, had moved away from a highly centralized global approach in the 1980 s, ceding more power to the country affiliates. But corporate crisis led the higher levels to claw back power in the 1990s. However, the renewed centralization was primarily at regional level and within businesses, rather than for the global corporation. In PharmaChem, which was the result of the merger of a pharmaceuticals and a chemical company, the fluctuation in the degree of central control partly reflected the clash of styles as one of the partners became dominant. The pharmaceuticals partner had been used to a decentralized style with considerable subsidiary autonomy. The other partner progressively imposed its own top-down 'tablets of stone' approach on the merged company, with a range of central interventions on such issues as pay criteria, performance appraisal, and the outsourcing of HR services. This in turn provoked resistance from subsidiaries used to greater independence (see below). EngCo2 had attempted to centralize and standardize international HR policy as the company became more of a global 
operator. A concern with cutting costs in the face of intensifying international competition led to cost-cutting. However, the increasing weight of operations outside the US also prompted moves to decentralize authority from corporate HQ to international business divisions, and provoked attempts by national subsidiaries to increase their influence on policy (see below). In Refreshco, worldwide expansion had been led from headquarters in a highly centralized fashion. As markets matured, the company moved toward a strategy of adapting global brands to local consumer tastes in order to maximize future market growth. Even in Eng Servs, the highly decentralized management of the UK subsidiary showed signs of erosion under the pressures of market changes, such as the increasing international integration of client firms, and of internal cost-cutting (see Colling and Clark 2002).

This 'ebb and flow', as one respondent called it, can be traced back to rapidly changing external conditions. International competition hitting US companies, often combined with accelerating technological change and merger movements, has increased market volatility sharply in recent decades. Although it is too early to identify with precision whether this picture is specific to American MNCs, the intense exposure of US companies to pressures from financial markets, encapsulated in the ideology of 'shareholder value' (see, for example, O'Sullivan 2000), is likely to have reinforced the volatility of management response. More fundamentally, the US business system's relative under-institutionalization, compared with the strong, relatively rigid institutional arrangements of, say, Germany, may encourage constant structural adjustment to changing market circumstances (Hollingsworth 1997).

But oscillation also reflects another characteristic that can be assumed to apply to MNCs more generally. As the above examples also illustrate, the degree of centralization was a negotiated and, at times, contested process; oscillation between centralization and autonomy may therefore be seen as a manifestation of the interplay of interests between MNC actors at different levels, rather than as a mechanical response to structural changes in the environment.

\section{The Negotiation of the Centralization-Autonomy Balance}

This negotiation of interests has, as noted, been a long-observed element in relations between MNC head offices and subsidiaries (for example, Brooke 1984; Martin and Beaumont 1999). But it was now being fuelled by objective structural changes, such as the growth of non-US markets and the trends described by writers such as Bartlett and Ghoshal (1998) and Hedlund (1986) toward a greater worldwide diffusion of strategic responsibilities within MNCs. These changes provided an enabling context in which subsidiaries could mount claims to greater international influence. At the same time, the 'ethnocentric' policy tendencies of US MNCs (deriving standardized global policies on the basis of what was appropriate for US conditions) also gave more incentive to subsidiaries to contest policy.

There were two arenas of negotiation: policy creation and policy implementation. There appeared to be a marked trend toward the increasing 
involvement of subsidiaries in the policy-development process, even where policy remained driven from the centre and standardized. The process of subsidiary inclusion was more advanced in companies, such as ITco, that had a long tradition of international operations and less advanced in others, such as EngCo2, which saw themselves as in the transition stage from being US companies with foreign operations to becoming fully international companies. In some cases, as in EngCol, an important trigger in opening up the international HR policy-making process seemed to be a sustained period of international growth through acquisitions, which not only shifted the centre of gravity in the company, but also brought in new expertise and perspectives. Another trigger was the development in several companies of strategic activities such as product design and development outside the USA, as was the case in $\mathrm{EngCol}$; this reflected the need to adapt products to the specific requirements of growing regional (or national) markets abroad.

The involvement of subsidiaries in HR policy-making took various forms. Country HR managers often had European 'hats', so that regionalization did not always involve as clear cut a reduction in subsidiary influence and autonomy as might be expected. In PharmaChem, for example, a European HR council brought together national HR managers and gave them Europewide HR responsibilities for different business divisions. Partly as a result of the strong country presence in European HR, the relationship between the European level and corporate HR was ambiguous. While the European level could be seen as an intermediate level of centralization and a means of exerting central control over the subsidiaries, it also provided national subsidiaries with a common voice and a means of interest aggregation vis-àvis central HR, and there were indications that it could align itself with the subsidiaries, fighting central proposals on their behalf. Where senior European HR managers had come from country subsidiaries, they often retained strong links with their country base and at the very least understood its perspective.

In some companies, subsidiaries had to struggle to win involvement in HR policy formulation. In EngCo2, where policy remained largely centralized and was becoming increasingly standardized worldwide, a senior HR manager from the UK subsidiary together with allies from other foreign subsidiaries initiated a major change in policy. At a global HR conference held by the corporate HR function, this group of subsidiary managers challenged US control over the HR policy agenda, and the lack of a global perspective in policy-making. They argued that since policies were designed by corporate HR without a subsidiary input, HQ 'then get a lot of pushback because it doesn't work in one region' (senior business-divisional HR manager). As a result, a number of international project teams were formed to design improvements in the process of policy generation through earlier HR input from the regions. One of the first fruits of the new policy was the secondment of a UK HR manager to the USA to head an international team developing a new global performance-management policy. EngCo2 therefore appeared to provide a case in which standardized global policy was being constructed in a decentralized, collective manner. However, such gains were tentative: corporate cost-cutting meant that international policy teams were unable to 
meet for long periods, possibly allowing seconded subsidiary managers to be 'co-opted' by central HR. It seems plausible to suggest that in general, headquarters groups disadvantaged by the internationalization of policymaking will use such eventualities to push back against the changes. We have no direct evidence that this happened in EngCo2, but the new performancemanagement system that emerged had little subsidiary input.

In terms of policy implementation, in practice larger, more successful subsidiaries (for example, EngCol or FMCG) had reasonable scope to interpret even nominally standardized policies in the light of local conditions - a finding that echoes studies of US MNC subsidiaries in Scotland (Tayeb 1998; Tayeb and Thory 2001). For example, a senior product manager in EngCol told of how a new global performance-appraisal system was adapted in the UK. Originally designed to decouple appraisal from pay determination so that these became two separate processes, the new scheme was resisted in the UK, where employees felt uncomfortable with it. As a result, the UK was allowed to retain the direct link between the appraisal score and the pay award. Even in ITco, one of the most standardized of the companies, there was de facto flexibility. An example concerned the highly standardized international system for recording the hours breakdown of customer-facing staff. One respondent claimed that as long as he complied formally with the system by entering values in the computerized hours matrix, there was no scrutiny or auditing of his responses.

In several firms, including EngCol and Householdl, flexibility was overtly permitted providing that non-compliance with central policy could be justified, and as long as the subsidiaries' actions did not 'compromise' central policy or the position of other facilities. In many instances, a subsidiary had a strong incentive to comply with central policies even where they were optional, since to do so was more cost-effective than 'reinventing the wheel' by developing its own.

An important lever for subsidiary management in negotiating the degree of (de)centralization was the existence of local institutional constraints on their activity. This allowed them to resist central pressure for a standardized policy. For example, $F M C G$ 's UK subsidiary resisted the regimented global policy on diversity on the grounds that positive discrimination was against UK law: 'we tend to use the legal argument as the best one, that's the one that's difficult for them to argue with' (UK HR director). This gambit could arouse considerable suspicion in corporate headquarters, however. For example, during an international redundancy programme in $F M C G$, as a senior UK respondent commented:

'They [US HQ] still think ... that the push-back they might get on this is because we don't want to do it. Not because we can't do it ... to the point where actually just a few weeks ago we did get our European legal director to drop a note back to the required people and say "here, look, this is not the soft touchy-feely HR people thing that you can't do this, you really can't do this!"”

This use of constraints in the local environment to achieve a relaxation of the constraints imposed by central company policy has been observed in other 
contexts (for example, Quintanilla 1998). In areas less clear cut than these statutory limitations on managerial freedom, local management has considerable leeway in the interpretation of the local environment and, consequently, in the determination of what is or is not a 'constraint'.

However, given central HR's suspicions, there was a limit to the 'local constraints' arguments, and subsidiary managers were very conscious of the need to put forward acceptable rationales for resisting central policy. An illustration is provided by a redundancy programme in EngCo2. HQ demanded a given level of job cuts worldwide on a rigid centrally determined timetable, but the UK company argued that it should have more time to achieve the reduction. The UK plant's resistance was not justified primarily by reference to UK legislation concerning redundancy (although that was an element), but rested, first, on a distinction between ends and means:

'I said, "tell me what you want as an end result okay, and let us tell you how we'll get there - don't tell us both where to get to and how to get there." Because what they were doing, they were applying US prescriptions to UK situations.' (UK HR manager)

The second element of the UK's rationale was to provide a business case for the proposed course of action. The UK argued that it already had a plan that would eventually lead to a greater reduction in numbers, while preserving staff morale and commitment. The case was helped by the unions' willingness to sing from the same hymn sheet and refrain from aggressive tactics that would have only provoked a reaction from the Americans. The UK's proposal was eventually accepted by the Americans, albeit reluctantly, and the subsidiary was allowed to do things its own way. Its success gave it added credibility with HQ, allowing it more easily to claim autonomy on subsequent issues. Had it failed, it is likely that its autonomy would have been more constrained in the future.

This example also illustrates the importance of the rhetorical aspect of negotiation. As the UK HR manager stressed, the language for dealing with the centre was important. You should not say:

“"Can't do that", and they don't like "you don't know how it works over here" either, because that makes them feel inadequate or it's again seen as a negative.... The word "why" comes up - [the US response is] "why not?", which then generates some conflicts. Those things I learned early on in that process, there were certain ways of responding to questions... The first thing you say is "yes" in an American company ... they don't like "no", it doesn't sound very can-do to them.'

Another source of leverage for managers in the subsidiaries was their ability to exploit tensions between one central policy and another. In PharmaChem, according to a senior UK HR manager, when the centre imposed a mandatory worldwide pay limit, it was strongly opposed by the British. Their counter-argument was that such a limit would undermine the company's preference for non-union, unitarist employment relations, since the unionized plant in North-West England would inevitably breach the limit and unionized employees would thus receive more than the non-union employees at the company's other main plant. When HQ HR executives responded that shop- 
floor employees at the non-union plant could be given a deal in excess of managerial employees, the UK HR function retorted that:

'We are trying to build a team-based, holistic, single-status organization, and we give differential pay increases!... We're transparent, we're open, we're honest, and [then] we do this! What message are we sending to people? We then cause an adversarial relationship to build up.... The whole philosophy of the site for 30-odd years has been non-union, non-divisive, all together. All for one, one for all. I said [to the US manager] "you can't overturn this sort of thing. Especially when it works and delivers... your number one product is packed at [the non-union plant]. Do we want a union getting in there, causing trouble? I don't think so. And I don't think the President Europe is going to be too keen."' (UK HR manager)

Transitions between degrees of centralization or decentralization could provoke tensions as they restructured power relations among different corporate interest groups and altered the resources available to them. In Refreshco, the centrally driven decentralization process appeared to generate two opposing kinds of conflict. On the one hand, local managers perceived that the US HR function was still finding it difficult to abandon its old centralizing reflexes; for example, it was said to be trying to globalize policy revisions introduced in the wake of diversity litigation affecting just the USA. On the other hand, decentralization caused problems because subsidiaries lost HQ support for policy implementation, and they had to invest resources in developing local-level capabilities for training and other policy areas previously provided centrally.

The micro-political dynamics of centre-subsidiary relations are complicated by what might be called the interpenetration of management elites. As already discussed, in several companies, individuals with HR responsibilities at regional level were also national subsidiary managers. Within subsidiaries, key roles were sometimes performed by expatriate managers who retained close links with corporate headquarters. In one company, senior American managers were in key posts as plant managers and heads of product groups and in senior roles in other functions, including HR. Senior UK operations managers (mostly US expatriates) were members of the international executive management team of the US-headquartered business division of which the UK operation was part. Hence, the UK subsidiary was highly integrated into the process of international policy-making and objective setting for the business. The boundaries between head office and the subsidiary were thus blurred.

Lastly, as the existence of de facto negotiation suggests, while formal centrally managed systems and policies were important, informality was also sometimes more pervasive than some accounts of the US mode of control might suggest. Most obviously, in firms in which the influence of the founding father was still strong, informality and personalism continued to coexist alongside formal and impersonal systems. In Household1, a decision to close the manufacturing operation in the UK and transfer production to the continent was reversed after being vetoed by the family. But even in some non-familyowned companies (EngCol was an example) things happened as much through consensus seeking, informal networking, and collegiality, as through formal 
processes and hierarchical authority. A senior HR manager in the UK spoke of a 'shared pool' of authority rather than central control. Negotiation took place to 'establish consensus' and 'make things happen'. At the UK level, a policy innovation of having 'shared services' in HR across the different businesses was established through 'negotiation' and 'partnership' between HR and the businesses rather than mandated through a hierarchical structure. This involved assiduously building up support from key managing directors, helping neutralize potential opposition to the initiative from the respective business-level HR functions.

As argued elsewhere, informal processes often provide important underpinnings for formal systems; without the former, the latter run the risk of being 'empty shells' with little effect on actual practice in the subsidiaries (Ferner 2000b). In this sense, informality may be seen as an important accompaniment of a formalized, centralized modus operandi. Nonetheless, the data indicate that the extent of informality was not a given, but depended on the presence of certain supporting factors. First, as suggested, in personalistic, family-owned firms the influence of the owning family could create parallel informal structures of influence. A second factor appeared to be size. Informality, particularly in horizontal networks, was more practicable in companies such as the two referred to above that were still relatively small by the standards of major multinationals, with tens of thousands of employees worldwide rather than hundreds of thousands. Indeed, managers at EngCol envisaged a decline in informal networking as the MNC grew in size and became more diverse. A final factor may be the presence of expatriates in senior management positions, especially noticeable again in EngCol, providing managers over time with an internationally disseminated web of contacts on which they can call.

\section{Discussion and Conclusions}

The article has examined through case-study evidence a characteristic trait of US MNCs: the centralization, standardization, and formalization of HR policy. While confirming much of the conventional picture, the article has attempted to go beyond existing approaches. First, where appropriate, it has suggested linkages between the nature of the centralization dynamic and the national origins of these MNCs. In particular, the development of distinctive 'organizational capabilities' in order to deliver standardized products to mass markets has provided the technical means and the managerial experience to manage overseas operations in a centralized, formalized, and standardized way. But, to the extent that patterns of centralization, standardization, and formalization in US MNCs are in practice underpinned by informal networks and understandings, the differences between the American model and other models of international management may be more muted than at first appears.

Second, qualifying conventional evolutionary 'stages of development' assumptions, the research has pointed to more contingent patterns of 'oscillation' between centralization and decentralization in response to the greater volatility of the external environment. The arguments about MNCs' 
rootedness in specific national business systems imply that the extent of oscillation is likely to vary. MNCs' responses to common external pressures are likely to be partly determined by the institutional characteristics of the country-of-origin business system. While in the context of the underinstitutionalized US business system, rapid changes of tack at the level of corporate structure are both permitted and expected, this may not be the case in more regulated business systems facing the same environmental pressures. Thus, the greater institutional rigidities of the German system, and companies' experience of operating in a stable and predictable environment, may be expected to dampen the ability of German-based MNCs to react to external change by rapid and flexible changes in organizational structures, not least because the institutional framework provides organizational actors (including unions and works councils) with greater power to resist changes in the status quo (compare Vitols 2001).

Third, the findings suggest the need to specify carefully the locus of 'centralization'. European integration has strengthened the importance of the European regional level in the determination of MNCs' HR policies, implying both a recentralization away from the national level and a relaxation of control from corporate HQ. A separate dynamic has seen the rise of international business divisions integrating productive activity across borders, with a corresponding devolution of HR issues from corporate HQ to businesses (and a centralization from the national subsidiary level). Sometimes these structural principles are in tension, as when the logic of the international business structure conflicts with cost-saving imperatives requiring greater crossbusiness centralization of HR, manifested in several companies in the concept of 'shared services'. Such tensions at the level of corporate organizational responses to external change may fuel the pattern of oscillation between centralization and decentralization, with complex shifts as between business and region.

Fourth, while oscillation undoubtedly reflects external changes and conflicting tendencies in MNC organizational structure, such changes have to be interpreted and acted upon by actors within the corporation. It has been argued, in contrast to the apolitical top-management perspective of much of the international corporate strategy literature, that centralization is constructed through the interaction of organizational actors at different levels. One important thread of argument is that the degree of centralization is not determined in a mechanical way by headquarters edict, but emerges out of a process of negotiation between head office and the subsidiary. In this process, the growing strategic importance of subsidiaries with the growth of markets outside the USA provides a basis for the increased bargaining power of hostcountry managers. In short, oscillation is partly a reflection of the negotiation process that underlies the definition of the centralization-autonomy balance in a given instance.

Fifth, a number of processes underpinning this negotiation of central control have been identified, and further research could explore how far they are typical of US and other kinds of MNC. These processes appear to be important in indicating how subsidiaries (not to mention head offices) actually deploy 
the power 'resources' that writers such as Ghoshal and Nohria (1989) have attributed to them. First, overt challenges and resistance to central control by subsidiaries in some cases rest on exploiting internal inconsistencies or complexities in corporate policy, as in the PharmaChem incident in which the subsidiary resisted central pay intervention by invoking the corporate principle of avoiding unions. The claimed adherence to one central policy thus provided a rhetoric of legitimation for avoiding compliance with another.

Second, subsidiary managers find leverage in their role as interpreters of the local environment, allowing them to resist centrally imposed standardization and to secure local modification of central policies. Institutional constraints within the host business system (for example, equal opportunities legislation or EU directives covering workforce consultation on redundancies) could be adduced as grounds for not complying with HQ policy. The significance for corporate action of the institutions of the local business system is to a degree indeterminate, and therefore becomes a terrain of combat between subsidiary and head office. However, US headquarters could be unsympathetic to subsidiary non-compliance on the grounds of local constraint (perhaps because of the relative lack of constraints on management action within the US business system) and hence one might expect greater limits to the use of this gambit by subsidiaries of US MNCs than by those of MNCs rooted in more regulated business regimes. Partly for this reason, there is evidence of close attention being paid by subsidiary managers to the 'legitimatory rhetoric' accompanying and justifying their resistance to central control. Actors at head office can take steps to reduce the 'interpretative gap' by despatching high-level expatriates to the subsidiaries - strengthening the local implementation of central policies by weakening subsidiary management's claims to specialist local knowledge.

Third, penetration by subsidiaries of the policy-making process (for example, through participation in international policy task forces and by occupying key posts in regional-level management structures) is a mechanism for softening the dominance of head office, so that standardized, formalized global policy becomes generated through a more collective process and is less likely to be seen by subsidiaries as a central initiative to be resisted. In order to engage with the policy-making process, subsidiary managers already will have had to deploy resources to build corporate credibility (compare Birkinshaw and Fry (1998) on how subsidiaries lobby for global 'charters') and may have to take account of the resistance of central actors whose roles are being undermined. Lastly, as this implies, functional managers at head office (for example, HR specialists responsible for policy generation) may well have power resources that allow them to resist decentralization, even when the devolution is sanctioned by top management. They may do so (as appeared to be the case in Refreshco) by latching on to key aspects of a corporate culture or policy agenda, such as 'diversity', in order to legitimate overseas interventions.

The findings of the study also have implications for broader questions concerning the routes of transmission, whereby 'American' traits are diffused within MNCs to their foreign operations. It is precisely the centralized 
and formalized systems of control over HR and IR (and in other areas of management) that may be expected to form the primary transmission channel for substantive traits in US MNCs, compared to the much greater use of personal control through expatriation as described in Japanese companies by writers such as Bartlett and Ghoshal (1998) (see also Harzing 1999).

A final issue concerns the generalizability of the findings, particularly concerning oscillation and negotiation, to issues other than HR. As has been found repeatedly in the literature, HR and IR issues are more likely to be subject to institutional host-country constraints than many other issues (Rosenzweig and Nohria 1994). Moreover, regulation covering employment issues is highly variable across issues and across national business systems. To this extent, HR is a particularly fertile terrain for the negotiating leverage provided by the subsidiary's position as 'interpreter' of host-context constraints for the corporate $\mathrm{HQ}$. One could hypothesize, therefore, that the scope for negotiation is correspondingly reduced for other issues. Nonetheless, HRM is not the only area where local 'interpretation' is relevant. In terms of marketing strategies, for example, the nuances of local demand and tastes may provide equivalent leverage to subsidiary management. Even in areas such as research and development, scope for negotiation over the extent of centralization may exist as companies try to exploit the comparative advantages of particular foreign locations resulting from particular research skills or relationships with local actors such as universities or governments. This may give local management a role as 'interpreter' of these capabilities for HQ, and thus enable it to negotiate over the precise degree of autonomy of local facilities. In short, the processes of negotiation observed with respect to the degree of centralization of HR are not prima facie restricted to HR. Similar oscillating patterns stemming from the 'ebb and flow' of negotiation may therefore be observable for other issues too.

In summary, the findings both confirm those of the existing literature and extend them by, first, providing a greater insight into the embeddedness of $\mathrm{MNC}$ practices in an American business system that is dynamic and evolving; second, by exploring the way in which centralization responds to different dynamics, both long-term evolutionary developments and short-term contingent and 'oscillating' pressures; and third, by arguing that these external pressures provide only a broad structural framework, within which the precise level and meaning of central control versus local autonomy is negotiated by actors at different organizational levels.

We are very grateful to Organization Studies' anonymous reviewers for some helpful and challenging comments. This article is part of the work of an international project on HRM in US multinationals in Europe, coordinated by the Department of HRM, Business School, De Montfort University, UK. The research is funded by the ESRC and the Anglo-German Foundation for the Study of Industrial Society. The other research teams are: in Germany, the University of Trier (Hartmut Waechter and René Peters), the University of Erfurt (Anne Tempel), and the International University in Germany, Bruchsal (Michael Muller-Camen); in Ireland, the University of Limerick (Paddy Gunnigle and Michael Morley); and in Spain, IESE Business School (Javier Quintanilla and Marta Portillo). The British team is grateful to the other teams for access to some of their interview data. These have been useful as an additional check on the validity of the main findings of the British study reported here. 


\section{References}

Adler, Nancy, and F. Ghadar

1990 'Strategic human resource management: A global perspective' in Human resource management: an international comparison. R. Pieper (ed.), 235-260. Berlin: De Gruyter.

Appelbaum, Eileen, and Rose Batt 1994 The new American workplace. Ithaca, New York: Cornell University Press.

Bartlett, Christopher, and Sumantra Ghoshal

1998 Managing across borders, 2nd edn. [1989] London: Hutchinson.

Bird, A., S. Taylor and S. Beechler

1998 'A typology of international human resource management in Japanese multinational corporations: Organizational implications'. Human Resource Management 37/2: 159-172.

Birkinshaw, Julian, and N. Fry

1998 'Subsidiary initiatives to develop new markets'. Sloan Management Review, spring, 39/3: 51-62.

Bomers, Geert, and R. Peterson 1977 'Multinational corporations and industrial relations: The case of West Germany and the Netherlands'. British Journal of Industrial Relations 15/1: 45-62.

Brooke, Michael Z.

1984 Centralization and autonomy. London: Holt, Rinehart and Winston.

Brooke, Michael Z., and L. Remmers 1970 The strategy of multinational enterprise. London: Longman.

Chandler, Alfred

1990 Scale and scope. The dynamics of industrial capitalism. Cambridge, MA: Belknap Press.

Child, John, David Faulkner, and Robert Pitkethly

2000 'Foreign direct investment in the UK 1985-1994: The impact on domestic management practice'. Journal of Management Studies 37/1: 141-166.
Colling, Trevor, and Ian Clark

2002 'Looking for "Americaness": Home-country, sector and firm effects on employment systems in an engineering services company'. European Journal of Industrial Relations 8/3: 301-324.

Dowling, Peter, Denice Welch, and Randall Schuler

1999 International human resource management, 3rd edn. Cincinnati, $\mathrm{OH}$ : South-Western College.

Doz, Yves, and C. Prahalad

1994 'Controlled variety: A challenge for human resource management in the MNC' in Globalizing management. V. Pucik, N. Tichy and C. Barnett (eds), 119-135. New York: Wiley.

Dunning, John

1998 American investment in British

[1958] manufacturing industry, revised and updated edn. London and New York: Routledge.

Edwards, Paul, Anthony Ferner, and

Keith Sisson

1993 'People and the process of management in the multinational company: A review and some illustrations'. Warwick Papers in Industrial Relations, No. 43. Coventry: IRRU.

Edwards, Richard

1979 Contested terrain. The transformation of the workplace in the twentieth century. London: Heinemann.

Ferner, Anthony

2000a' The embeddedness of US multinational companies in the US business system: Implications for HR/IR'. Occasional Paper No. 61. Leicester: De Montfort University School of Business.

Ferner, Anthony

$2000 \mathrm{~b}$ 'The underpinnings of "bureaucratic" control systems: HRM in European multinationals'. Journal of Management Studies 37/4: 521-540.

Forsgren, Mats

1990 'Managing the international multicentre firm'. European Management Journal 8/2: 261-267. 
Ghoshal, Sumantra, and Nitin Nohria 1989 'Internal differentiation within multinational corporations'. Strategic Management Journal 10: 323-337.

Ghoshal, Sumantra, and Nitin Nohria 1993 'Horses for courses: Organizational forms for multinational corporations'. Sloan Management Review 34/2: 23-36.

Guest, David, and Kim Hoque

1996 'National ownership and HR practices in UK greenfield sites'. Human Resource Management Journal 6/4: 50-74.

Gunnigle, Patrick

1995 'Collectivism and the management of industrial relations in greenfield sites'. Human Resource Management Journal 5/3: 24-40.

Hamill, Jim

1984 'Labour relations decision making in multinational corporations'. Industrial Relations Journal 15/2: 30-34.

Harzing, Anne-Wil

1999 Managing the multinationals: An international study of control mechanisms. Cheltenham: Edward Elgar.

Hedlund, Gunnar

1986 'The hypermodern MNE'. Human Resource Management 25: 9-36.

Hofstede, Geert

1980 Culture's consequences. London: Sage.

Hollingsworth, John Rogers

1997 'Continuities and changes in social systems of production: The cases of Japan, Germany, and the United States' in Contemporary capitalism. The embeddedness of institutions. J. R. Hollingsworth and R. Boyer (eds), 265-308. Cambridge: Cambridge University Press.

Jacoby, Sanford

1997 Modern manors. Welfare capitalism since the New Deal. Princeton, NJ: Princeton University Press.
Kochan, Thomas, Harry Katz, and Robert McKersie

1986 The transformation of American industrial relations. Ithaca: ILR/Cornell University Press.

Kopp, Rochelle

1994 'International human resource policies and practices in Japanese, European, and United States multinationals'. Human Resource Management 33/4: 581-599.

Kujawa, Duane

1979 'The labour relations of United States multinationals abroad: comparative and prospective views'. Labour and Society 4/1: $1-25$.

Lindholm, N., M. Tahvanainen, and

I. Björkman

1999 'Performance appraisal of host country employees: Western MNEs in China' in International HRM: Contemporary issues in Europe. C. Brewster and H. Harris (eds), 143-159. London: Routledge.

Marginson, Paul

2000 'The Eurocompany and Euro industrial relations'. European Journal of Industrial Relations 6/1: 9-34.

Marginson, Paul, and Keith Sisson 1994 'The structure of transnational capital in Europe: The emerging Euro-company and its implications for industrial relations' in $\mathrm{New}$ frontiers in European industrial relations. R. Hyman and A. Ferner (eds), 15-51. Oxford: Blackwell.

Martin, Graham, and Phil Beaumont

1999 'Co-ordination and control of human resource management in multinational firms: The case of CASHCO'. International Journal of Human Resource Management 10/1: 21-42.

Martínez, J., and J-C. Jarillo

1989 'The evolution of research on coordination mechanisms in multinational corporations'. Journal of International Business Studies, fall: 489-514. 
Mtar, Monia

2001 'French multinationals' international strategy: National identity under the effect of globalisation'. $\mathrm{PhD}$ thesis. Coventry: University of Warwick.

Negandhi, Anand

1983 'External and internal functioning of American, German, and Japanese multinational corporations:

Decisionmaking and policy issues' in Multinational corporations.

M. Casson (ed.), 557-577.

Aldershot: Edward Elgar.

Negandhi, Anand

1986 'Role and structure of German multinationals: A comparative profile' in European approaches to international management. K. Macharzina and W. Staehle (eds), 51-66. Berlin and New York: Walter de Gruyter.

Ngo, H., D. Turban, C. Lau, and S. Lui

1998 'Human resource practices and firm performance of multinational corporations: Influences of country origin'. International Journal of Human Resource Management 9/4: 632-652.

O’Sullivan, Mary

2000 Contests for corporate control. Oxford: Oxford University Press.

Perlmutter, Harry

1969 'The tortuous evolution of the multinational firm'. Columbia Journal of World Business, January-February: 9-18.

Quintanilla, Javier

1998 'The configuration of HRM policies in multinational subsidiaries: The case of European retail banks in Spain'. PhD thesis. Coventry: University of Warwick.

Roberts, Brian

1972 'Factors influencing the organization and style of management and their effect on the pattern of industrial relations in multi-national corporations' in Transnational industrial relations. H. Günter (ed.), 109-132. London: Macmillan.

Rosenzweig, Philip, and Nitin Nohria 1994 'Influences on human resource management practices in multinational corporations'. Journal of International Business Studies 25/2: 229-251.
Royle, Tony, editor

2000 Working for McDonald's in Europe. London: Routledge.

Tayeb, Monir

1998 'Transfer of HRM policies and practices across cultures: An American company in Scotland'. International Journal of Human Resource Management 9/2: 332-358.

Tayeb, Monir, and Kathryn Thory

2001 'Americans in Europe: The case of 10 US MNCs and their HRM in Scotland'. Paper presented to the ESRC Conference on Multinational Enterprises: Embedded Organizations, Transnational Federations or Global Learning Communities?, 6-8 September, University of Warwick, Coventry.

Taylor, S., S. Beechler, and N. Napier 1996 'Toward an integrative model of strategic international human resource management'. Academy of Management Review 21/4: 959-985.

Vitols, Sigurt

2001 'Varieties of corporate governance: Comparing Germany and the UK' in Varieties of capitalism. The institutional foundations of comparative advantage. P. Hall and D. Soskice (eds), 337-360. Oxford: Oxford University Press.

Wever, Kirsten

1995 'Human resource management and organizational strategies in Germanand US-owned companies'. International Journal of Human Resource Management 6/3: 606-625.

Young, S., N. Hood, and J. Hamill

1985 Decision-making in foreign-owned multinational subsidiaries in the United Kingdom. ILO Working Paper No. 35. Geneva: ILO.

Yuen, E., and Hui Tak Kee

1993 'Headquarters, host-culture and organizational influences on HRM policies and practices'.

Management International Review 33/4: 361-383. 
Anthony Ferner Anthony Ferner is Professor of International HRM at Leicester Business School, De Montfort University. His research interests focus on the interplay of globalizing pressures and national business systems in the management of employment relations within multinationals.

Address: Department of HRM, Room 3.20, Bosworth House, Leicester Business School, De Montfort University, Southgates, Leicester LE1, UK.

E-mail:afhum@dmu.ac.uk

Phil Almond

Phil Almond is Lecturer in HRM at Leicester Business School, De Montfort University.

E-mail:palmond@dmu.ac.uk

Ian Clark

Ian Clark is Principal Lecturer in the Department of HRM, Leicester Business School, De Montfort University.

E-mail: iachum@dmu.ac.uk

Trevor Colling Trevor Colling is Senior Research Fellow in the Department of HRM, Leicester Business School, De Montfort University.

E-mail: tchum@dmu.ac.uk

Tony Edwards Tony Edwards is Lecturer in Management at King's College, London.

Address: The Management Centre, King's College, 150 Stamford Street, London, SE1 9NN, UK.

E-mail: tony.edwards@kcl.ac.uk

Len Holden Len Holden is Principal Lecturer in the Department of HRM, Leicester Business School, De Montfort University.

E-mail:1thhum@dmu.ac.uk

Michael Muller- Michael Muller-Camen is Associate Professor of International Management at the Camen

International University in Germany.

Address: School of Business Administration, the International University in Germany, D-76646, Bruchsal, Germany.

E-mail: michael.muller-camen@i-u.de 